\title{
Padre Ernesto Cardenal: Ante Reina Sofía
}

Su Majestad:

Recibido: 24 de septiembre de 2012 / Aprobado: 01 de octubre de 2012

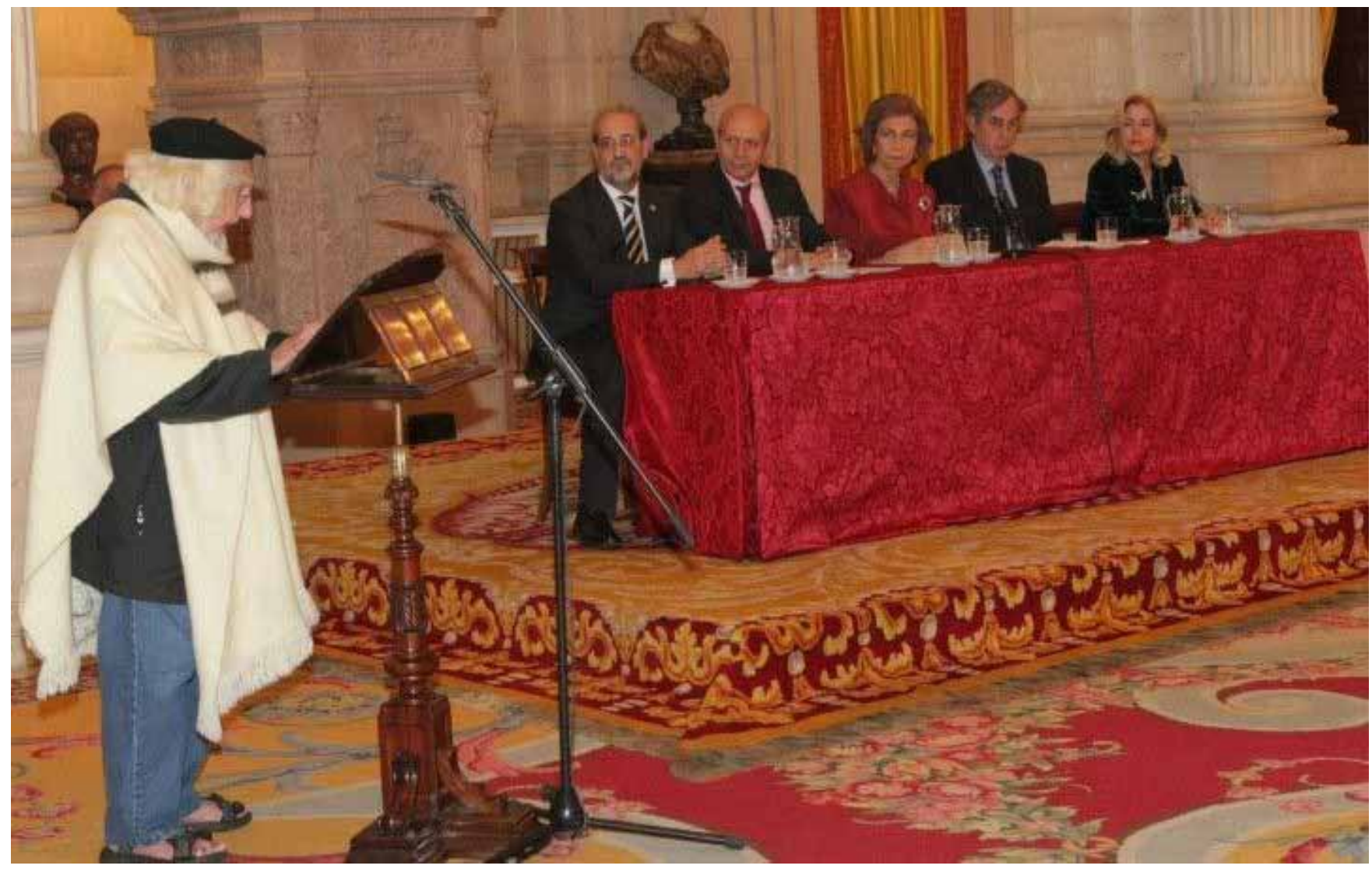

$\Lambda$ nte todo quiero expresar $\mathrm{mi}$ profundo agradecimiento al Patrimonio Nacional y la Universidad de Salamanca por haber decidido otorgarme este honrosísimo premio sin que tenga mucho mérito (otros con más mérito podrían ahora estar aquí en vez mía) y a Su Majestad Reina Sofía, en cuyo nombre se me otorga este premio. Que la poesía sea promovida por una reina es algo que debieran imitar los otros gobernantes. Y el que lo que ahora se me otorga sea llamado Premio Reina Sofía me parece que tiene un significado muy especial.

Sofía que en la lengua materna de Su Majestad significa
Sabiduría y es una figura muy misteriosa y muy atractiva de la Biblia. Ella habla de sí misma en el libro de Los Proverbios diciendo que Dios la tenía ya antes de su creación. Y antes que existieran los grandes mares, antes que brotaran los ríos y los manantiales, antes que se formaran los cerros y los montes, ella jugueteaba con la creación y estaba feliz entre los hombres.

La tradición cristiana ha interpretado esta figura de la Biblia como un atributo de Dios, como Dios en su creación y también como Cristo, Sabiduría de Dios, y Palabra creadora de Dios. En este caso yo creo que es como decir que Sofía es la Poesía de Dios. 
Podemos preguntarnos qué es poesía. Está la inmortal respuesta del poeta romántico andaluz Gustavo Adolfo Bécquer que dijo a su amada de ojos azules que se lo preguntó:

\section{Poesía eres tú}

Poesía es la persona amada, y pareciera que no hay nada más qué decir. Hay algo más que decir: Poesía es el amor. Y poesía es la amada que uno ama, y todo lo que uno ama y que lo ama a uno. Poesía es todo, incluido el Creador de todo. Poesía es Dios.

En griego, poeta es Poétés, que quiere decir "creador", y es palabra que se aplica lo mismo a Homero que a Dios. Así cuando San Pablo habla de la Creación, le llama Poema, igual que como se habla del poema de Homero.

Y así cuando Dios decide comunicarse con el hombre, que fue con los profetas, lo hace en poesía. Los profetas de la Biblia son grandes poetas. Como cuando Jeremías dice: "Sus carros de guerra son como un huracán, sus caballos son más ligeros que las águilas". O Ezaquiel habla de los que "atrapan a la gente como a pájaros". Y Zacarías dice: "Como se alegran los que se reparten el botín". Y el salmista dice: "Los que se comen a mi pueblo como si fuera pan".

La poesía, que también ha sido el lenguaje de Dios, fue el primer lenguaje de la humanidad, siendo el lenguaje lo que nos hizo humanos y nos diferencia de los animales. Y aun hoy la poesía sigue siendo la más eficaz comunicación humana. Todos los pueblos han comenzado teniendo poesía, antes que se desarrollen en ellos otros géneros literarios. Muy bien ha dicho Emerson que el lenguaje es poesía fósil: está lleno de imágenes que antes fueron brillante poesía y ahora están muy lejos de recordarnos su origen poético.

Un gran amigo y mentor mío, el poeta nicaragüense José Coronel Urtecho, nos decía que todo hombre es poeta como todo pájaro canta, aunque en muchos la educación atrofia la poesía.

En realidad en los pueblos primitivos, en aquellos cuya civilización es aún primitiva, todos son poetas. "Todo indio es un poeta en potencia" dice Grave Day. En
Dahomey, dice Jacob Drachler, la poesía es una ocupación cotidiana. En las islas Andaman todo mundo compone cantos. Entre los tuareg de África todos hacen versos, y lo mismo ocurre en muchas tribus indígenas de los Estados Unidos. En la antigua Grecia todo estaba escrito en verso, aun las leyes; y en muchos pueblos primitivos no existe más que el verso. Según una antigua tradición islámica Adán en el paraíso hablaba en verso.

También, y muy especialmente, se puede decir que todo niño es poeta. Yo dirijo junto con otros en un hospital de Managua un taller de poesía de niños con cáncer, y es asombrosa la poesía que brota de ellos espontáneamente. Un niño hablando de las ranas dice que sus caras parecen gente fea cuando se están riendo, y otro dice que la bocota del sapo es como la bocota de un señor gordo. Otro dice que los pichones de las guacamayas son pelones y cieguitos, y otro habla de que los periquitos cuando están chiquitos son peladitos como que les han puesto quimio.

Me parece que tiene mucha importancia teológica el poema de un niño de 10 años que recordando a amiguitos muertos dice que mientras se divertían jugando hablaban de "qué hacer cuando nos muramos". Está afirmando ingenuamente, y tal vez inconscientemente, la resurrección. La ve como un acontecer cotidiano, igual que sus juegos. Y yo pienso que no debemos temer a la muerte, como aquel niño enfermo no tenía ningún miedo, esperaba jugar más.

Voy a terminar con la frase que hace pocos días, acompañada de un cariñoso saludo me escribió mi amigo el gran obispo del Brasil Pedro Casaldáliga: “¿Quién dijo miedo habiendo Pascua?"

Esto también nos enseña Sofía, la Sabiduría y la Poesía de Dios.

Muchas gracias.

Ernesto Cardenal 